\title{
p53 gene mutations in multiple myeloma
}

R G Owen, S A A Davis, J Randerson, A C Rawstron, F Davies, J A Child, A S Jack, G J Morgan

\section{Centre for \\ Haematological \\ Oncology, Institute of Pathology, The \\ General Infirmary at Leeds, Great George \\ Street, Leeds LS1 3EX \\ Correspondence to: Dr G J Morgan.}

Accepted for publication 12 December 1996

\begin{abstract}
Aim-To assess whether p53 gene mutation is important in the pathogenesis and progression of multiple myeloma.

Methods-Thirty eight DNA samples (derived predominantly from bone marrow) obtained from 31 patients with multiple myeloma were examined for mutations in p53 exons 5-9 by polymerase chain reaction single strand conformation polymorphism. Twenty three samples were analysed at the time of diagnosis (one patient had plasma cell leukaemia), three in plateau phase, and 12 at relapse (one plasma cell leukaemia and one extramedullary relapse).

Results-One p53 mutation was detected in this group of patients $(3.2 \%)$. This was seen in the diagnostic bone marrow sample of a 35 year old man with stage IIA disease and occurred in exon 6 as a result of a silent $A$ to $G$ transition at codon 213 (CGA $\rightarrow$ CGG), a polymorphism that has been reported in about $3 \%$ of breast and lung tumours.

Conclusions-p53 gene mutations are rare events in multiple myeloma and would seem to be of limited value as a prognostic factor.

(F Clin Pathol: Mol Pathol 1997;50:18-20)
\end{abstract}

Keywords: p53; multiple myeloma.

p53 is a nuclear phosphoprotein encoded by a gene located on the short arm of chromosome $17(17 \mathrm{p} 13)$ which is capable of blocking cells at the G1/S transition, thereby halting the proliferation of DNA damaged cells and promoting apoptosis. Point mutations of the p53 gene have been demonstrated in a wide variety of solid tumours ${ }^{1-5}$ where they are usually associated with loss of the other allele. The resultant loss of p53 function mediates resistance to chemotherapy induced apoptosis, an event often associated with a poor clinical outcome. A vast number of $\mathrm{p} 53$ mutations has been described. They occur throughout the genomic sequence but most seem to be clustered in the central hydrophobic core of the molecule coded for by exons $5-9 .^{6}$

The incidence of p53 mutation in haematological malignancy is variable: a relatively high incidence has been reported in high grade lymphoma, Hodgkin disease, and acute myeloid leukaemia but mutations are rare events in myelodysplastic syndrome, acute lymphoblastic leukaemia (ALL), chronic lymphocytic leukaemia (CLL), and chronic myeloid leukaemia (CML). ${ }^{7}$ p53 mutations are, however, fre- quently associated with progressive disease with a poor prognosis, such as CML blast crisis, Richter syndrome, and transformation of low grade lymphoma. ${ }^{7}$

The role of p53 gene mutations in the pathogenesis of multiple myeloma and their potential use as a prognostic indicator remain uncertain. Therefore, we have used the widely accepted technique of polymerase chain reaction single strand conformation polymorphism (PCR-SSCP) analysis to detect $\mathrm{p} 53$ mutations in tumour samples obtained from 31 patients with multiple myeloma.

\section{Methods}

The study population comprised 31 patients (median age 56.5 years) with multiple myeloma (15 IgG, $11 \mathrm{IgA}$, one IgD, and four light chain) as defined by standard criteria. Twenty three patients were studied at diagnosis: 20 had symptomatic myeloma necessitating subsequent chemotherapy, two patients had plasma cell leukaemia, and the remaining patient had smouldering myeloma. ${ }^{8}$ Bone marrow aspirates containing a minimum of $10 \%$ plasma cells were obtained in each case. A further three bone marrow samples were obtained from three patients in plateau phase. Twelve samples were also obtained from 10 patients at time of relapse; these consisted of bone marrow in 10 cases, peripheral blood in a case of plasma cell leukaemia, and a skin biopsy specimen from a patient who relapsed with extramedullary disease. In each case, the tumour specimen contained a minimum of $10 \%$ plasma cells.

\section{PREPARATION OF DNA}

High molecular weight DNA was obtained from tumour samples by proteinase $\mathrm{K}$ digestion, phenol-chloroform extraction and cold ethanol precipitation.

\section{PCR-SSCP ANALYSIS}

The oligonucleotide primers used to amplify p53 exons 5-9 are listed in table 1. PCR reactions were performed in $50 \mu \mathrm{l}$ volumes with 20-50 pg DNA, 50 pmoles sense and antisense primers in buffer containing $20 \mathrm{mM}$ $\left(\mathrm{NH}_{4}\right)_{2} \mathrm{SO}_{4}, 75 \mathrm{mM}$ Tris- $\mathrm{HCl}(\mathrm{pH} \mathrm{9.0)}, 0.01 \%$ Tween, $1.5 \mathrm{mM} \mathrm{MgCl}_{2}$, and $50 \mathrm{mM}$ each dNTP. The reaction mixtures were held at $95^{\circ} \mathrm{C}$ prior to the addition of 0.5 units of Taq polymerase (Thermoprime; Advanced Biotechnologies, Surrey, UK). PCR amplification conditions for exons $5,6,8$, and 9 were $95^{\circ} \mathrm{C}$ for 40 seconds, $62^{\circ} \mathrm{C}$ for 40 seconds, and $72^{\circ} \mathrm{C}$ for 40 seconds for 35 cycles followed by a further 90 second extension at $72^{\circ} \mathrm{C}$. PCR amplification of exon 7 differed slightly in that the annealing temperature was increased to $65^{\circ} \mathrm{C}$. 
Table 1 Primer sequences used for the PCR amplification of p53 gene exons 5-9

\begin{tabular}{ll}
\hline Exon (base pairs) & Primer sequence (5'-3') \\
\hline $5(220)$ & F: CTTCCTCTTCCTACAGTACTC \\
& R: GCCCCAGCTGCTCACCATC \\
$6(148)$ & F: CTCACTGATTGCTCTTAGGTC \\
$7(170)$ & R: CCAGTTGCAACCAGACCTC \\
$8(163)$ & F: GTCTCCCCAAGGCGCACTGG \\
$9(111)$ & R: CAAGTGGCTCCTGACCTGGA \\
& F: CAATCCTGAGTAGTGGTAATC \\
& R: TGTCCTGCTTGCTTACCTCG \\
\hline
\end{tabular}

$F=$ forward primer $\mathbf{R}=$ reverse primer.

For SSCP analysis, 1.5-3 $\mu$ l each PCR reaction product was added to $10 \mu \mathrm{l}$ loading buffer and denatured at $80^{\circ} \mathrm{C}$ for 10 minutes before quenching on ice for several minutes. The denatured samples were then loaded onto FMC Mutation Enhancement Gel (FMC BioProducts; Rockland, Maine, USA) and electrophoresed at a constant $10 \mathrm{~W}$ for two to six hours depending on the fragment size. The gels were then fixed and the PCR fragments stained with silver.

DIRECT SEQUENCING OF PCR PRODUCTS

Abnormal bands were excised from the gel, eluted into $100 \mu \mathrm{l}$ distilled $\mathrm{H}_{2} \mathrm{O}$, and $2 \mu \mathrm{l}$ aliquots were then reamplified with identical primers and conditions. This PCR product was run on $2 \%$ agarose gel, purified with a Qiaquick gel extraction kit (Qiagen $\mathrm{GmBH}$, Hilden, Germany) and then sequenced in both directions using an Applied Biosystems (Warrington, UK) fluorescence ddNTP sequencing kit according to the manufacturer's instructions. The products of the sequencing reactions were then analysed using an Applied Biosystems DNA sequencer (Model 373A), equipped with sequence collection and analysis software, and compared with the known p53 sequence.

\section{Results}

Thirty eight samples of genomic DNA were obtained from 31 patients with confirmed multiple myeloma and analysed for p53 mutations by PCR-SSCP for exons 5-9. In each case, the tumour sample contained a minimum of $10 \%$ plasma cells. Normal SSCP patterns were observed in $37 / 38$ samples, whereas an abnormal exon 6 band was observed in the remaining sample. This was a diagnostic bone marrow sample obtained from a 35 year old man with stage IIA disease who is currently alive and in complete remission 42 months following autologous bone marrow transplantation. Direct sequencing demonstrated a silent A to $\mathrm{G}$ transition at codon 213 (CGA $\rightarrow$ CGG both coding for arginine) which was also demonstrated in somatic DNA samples (data not shown).

\section{Discussion}

The aim of this study was to investigate the degree to which $\mathrm{p} 53$ gene mutation contributes to the pathogenesis and progression of multiple myeloma, and whether their detection should be included in routine prognostic factor assessment. We studied 38 DNA samples obtained from 31 patients with PCR-SSCP for p53 exons 5-9 and found a single mutant band. This was demonstrated in the diagnostic bone marrow samples of a 35 year old man with stage IIA disease. Direct sequencing demonstrated this to be caused by a silent $A$ to $G$ transition at codon 213. This polymorphism has been described previously in about 3\% of lung and breast tumours, 9 and was also demonstrated in the somatic DNA in our patient. This finding clearly emphasises the importance of sequencing abnormal SSCP bands, particularly as this polymorphism results in the loss of a Taq1 restriction site.

This low frequency of mutation is likely to be a real phenomenon as mutations occurring outside exons 5-9 are rare in other tumour types, ${ }^{6}$ and all tumour specimens analysed in this study contained a sufficient proportion plasma cells-that is, a minimum of $10 \%$. It is possible, however, that we missed some mutant bands whose mobilities were similar to that of wild type p53. Our results are in accordance with other PCR-SSCP based studies which have reported a mutation frequency of $2-4 \% .^{10-12}$ Interestingly, germline mutations have not been demonstrated in individuals with two or more relatives with multiple myeloma. ${ }^{12}$

PCR-SSCP, however, is not sufficiently sensitive to demonstrate mutations occurring in minor subclones which can subsequently be responsible for relapse. This phenomenon has recently been demonstrated in acute leukaemia ${ }^{13}$ but is unlikely to be major factor in multiple myeloma as we were unable to demonstrate any mutant bands in the 12 samples obtained at relapse. p53 gene mutation may, however, have a role in a certain proportion of patients; Mazars et $a l^{14}$ demonstrated mutations in eight of 10 human myeloma cell lines derived from patients in the terminal phases of their disease, although, of course, these may have been acquired in vitro. Analysis of clinically derived material with PCR-SSCP and DNA sequencing have also demonstrated mutations in up to $40 \%$ of patients with end stage disease and plasma cell leukaemia. ${ }^{15-17}$ We were, however, unable to demonstrate mutations in three patients with plasma cell leukaemia and a further patient with end stage extramedullary disease.

We conclude that p53 mutation is a rare event in multiple myeloma and would seem to be of limited value as a prognostic indicator. When detected, mutations seem to be confined to patients with end stage and leukaemic forms of the disease, a situation analogous to $\mathrm{CML}$ blast crisis, Richter syndrome, and transformation of follicular lymphoma.

This work was supported by the Leukaemia Research Fund and the Yorkshire Cancer Research Campaign.

Baker SJ, Fearon ER, Nigro JM, Hamilton SR, Presinger AC, Jessup JM, et al. Chromosome 17 deletions and p53 gene mutat $217-21$.

2 Nigro JM, Baker SJ, Preisinger AC, Jessup JM, Hostetter R, Cleary $\mathrm{K}$, et al. Mutations in the $\mathrm{p} 53$ gene occur in diverse human tumour types. Nature 1989;342:705-8.

3 Pressor J, Thompson AM, Granston G, Evans HJ. Evidence that $\mathrm{p} 53$ behaves as a tumor suppressor gene in sporadic breast cancer. Oncogene 1990;5:1573-9. 
4 Takashashi T, Nau MM, Chiba I, Birrer MJ, Rosenberg RK, Vinocour M, et al. p53: A frequent target for genetic abnormalities in lung cancer. Science 1989;246:491-4.

5 Hsu I, Metcalf R, Sun T, Welsh J, Wang N, Harris C. Mutational hotspot in the p53 gene in human hepatocellular carcinomas. Nature 1991;350:427-8.

6 Hollstein M, Sidransky D, Vogelstein B, Harris C. p53 Mutations in human cancer. Science 1991;253:49-53.

7 Imamura J, Miyoshi I, Koeffler HP. p53 in haematologic malignancies. Blood 1994;84:2412-21.

8 Kyle RA, Griepp PR. Smouldering multiple myeloma. $N$ Engl F Med 1980;302:1347-9.

9 Carbone D, Chiba I, Mitsudomi T. Polymorphism at codon 213 within the p53 gene. Oncogene 1991;6:1691-2.

10 Preudhomme C, Facon T, Zandecki M, Vanrumbeke M, Lai $\mathrm{JL}$, Nataf E, et al. Rare occurrence of p 53 gene mutations in multiple myeloma. Br F Haematol 1992;81:440-3.

11 Yasuga Y, Hirosawa S, Yamamoto K, Tomiyama J, Nagata $\mathrm{K}$, Aokia N. N-ras and p53 gene mutations are very rare events in multiple myeloma. Int f Hematol 1995;62:91-7.

12 Willems PMW, Kuypers A, Meijerink J, Holdrinet R, Mensink E. Sporadic mutations of the p53 gene in multiple myeloma and no evidence for germline mutations in three familial mutiple myeloma pedigrees. Leukemia 1993;7: 986-91.

13 Zhu YM, McQuaker IG, Russell NH. Relapse of adult leukaemia is frequently associated with the presence of p53 mutations which are only detectable in a minor subclone at presentation [abstract]. Br f Haematol 1996;93(Suppl 1):54.

14 Mazars GR, Portier M, Zhang XG, Jourdan M, Bataille R, Theillet $\mathrm{C}$, et al. Mutations of the p53 gene in human myeloma cell lines. Oncogene 1992;7:1015-8.

15 Portier M, Moles JP, Mazars GR, Jeantur P, Bataille R, Klein $\mathrm{B}$, et al. p53 and RAS gene mutations in multiple myeloma. Oncogene 1992;7:2539-43.

16 Neri A, Baldini L, Trecca D, Cro L, Polli E, Maiolo AT. p53 gene mutations in multiple myeloma are associated with advanced forms of malignancy. Blood 1993;81:128-35.

17 Corradini P, Inghirami G, Astolfi M, Ladetto M, Voena C, Ballerini $\mathrm{P}$, et al. Inactivation of tumor suppressor genes, p53 and Rbl, in plasma cell dyscrasias. Leukemia 1994;8:758-67. 